\title{
ANALISIS MODEL DAN IDENTIFIKASI FAKTOR PENDUKUNG DAN PENGHAMBAT DALAM PROSES REKRUTMEN BAGI TENAGA KERJA PENYANDANG DISABILITAS FISIK DI KOTA SERANG
}

\author{
Melani Dwi Agustini', Arta Rusidarma Putra ${ }^{2}$, Isnaini Mahuda ${ }^{3}$ \\ 1,2,3 Universitas Bina Bangsa \\ melanidwi797@gmail.com
}

\begin{abstract}
ABSTRAK
Sulitnya penyandang disabilitas di Kota Serang dalam mendapatkan pekerjaan baik di instansi pemerintah maupun di perusahaan swasta, padahal hak mendapatkan pekerjaan sudah didukung oleh Perda UU Nomor 13 Tahun 2019. Salah satu penyebabnya adalah faktor pendukung dan penghambat dalam proses rekrutmen sehingga menimbulkan masalah dalam model rekrutmen penyandang disabilitas. Tujuan penelitian adalah menganalisis model rekrutmen dan mengidentifikasi faktor pendukung dan penghambat proses rekrutmen penyandang disabilitas fisik di Kota Serang. Penelitian ini menggunakan metode kualitatif deskriptif, teknik pengumpulan data menggunakan wawancara, observasi dengan pihak terkait dan studi dokumen. Hasil penelitian adalah model rekrutmen penyandang disabilitas sangat berhubungan dengan faktor pendukung dalam proses rekrutmen calon tenaga kerja penyandang disabilitas diantaranya kemampuan ( $s k i l l$ ), relasi dan pendidikan, sedangkan faktor penghambatnya yaitu kurangnya dukungan keluarga, semangat diri sendiri, aksesbilitas dan lingkungan. Kesimpulan dari penelitian ini adalah terdapat beberapa kendala pada model rekrutmen, yaitu ketersediaan sumber daya berkualitas yang terbatas, rendahnya tingkat pendidikan dan pengetahuan serta kriteria yang tidak dapat dipenuhi calon karyawan yang sangat berhubungan dengan faktor pendukung dan penghambat dalam proses rekrutmen calon tenaga kerja penyandang disabilitas fisik di Kota Serang. Adanya faktor penghambat dalam proses rekrutmen mengakibatkan faktor pendukung tidak berjalan dengan optimal, sehingga menyebabkan berbagai kendala dalam model rekrutmen yang ada.
\end{abstract}

\section{Kata Kunci : Model Rekrutmen, Faktor Pendukung, Faktor Penghambat, Disabilitas Fisik}

\section{ABSTRACT}

The difficulty of people with disabilities in Serang City in getting a job both in government agencies and in private companies, even though the right to get a job has been supported by Law Regulation No. 13 of 2019. One of the causes is supporting factors and obstacles in the recruitment process that cause problems in the recruitment model of people with disabilities. The purpose of the study is to analyze recruitment models and identify supporting factors and inhibit the recruitment process of people with physical disabilities in Serang City. This research uses descriptive qualitative methods, data collection techniques using interviews, observations with relevant parties and document studies. The results of the study are that the recruitment model of people with disabilities is closely related to supporting factors in the recruitment process of prospective workers with disabilities including skills, relationships and education, while the inhibiting factors are lack of family support, self-spirit, accessibility and environment. The conclusion of this study is that there are several obstacles to the recruitment model, namely the availability of limited quality resources, low levels of education and knowledge and criteria that cannot be met by prospective employees 
Prosiding The 1st National Conference on Applied Business, Education, \& Technology (NCABET)"

Unversitas Bina Bangsa 2021

DOI Article : 10.46306/ncabet.v1i1.9

who are closely related to supporting factors and obstacles in the recruitment process of prospective workers with physical disabilities in Serang City. The existence of inhibitory factors in the recruitment process resulted in supporting factors not running optimally, thus causing various obstacles in the existing recruitment model.

\section{Keywords: Recruitment Model, Supporting Factors, Inhibitory Factors, Physical Disabilities}

\section{PENDAHULUAN}

Sumber Daya Manusia merupakan elemen terpenting dalam suatu perusahaan untuk bisa terus bertahan dan berkembang. Sebab, suatu perusahaan akan sukses jika memiliki SDM yang berkualitas dalam pekerjaannya. Oleh karena itu, untuk mendapatkan SDM yang berkualitas tentuharus melalui proses rekrutmen yang tak mudah. Rekrutmen bagi penyandang disabilitas harus disusun dengan standar operasional prosedur yang matang dan jelas. Kendala yang umumnya dihadapi pada saat rekrutmen adalah kurangnya ketersediaan SDM yang berkualitas, tingkat pendidikan dan pengetahuan yang rendah serta batasan kriteria yang tidak dapat dipenuhi oleh calon karyawan seperti kelengkapan berkas lamaran yang tidak memenuhi syarat. Sulitnya penyandang disabilitas dalam memperoleh pekerjaan di kota serang ini harus medapat perhatian serius karena apabila tidak maka hal ini akan menimbulkan dampak sosial lainnya seperti pengangguran bahkan kemiskinan khususnya di Kota Serang. Salah satu hal yang dapat dilakukanuntuk menanggapi hal tersebut adalah melalui kesempatan kerja yang diberikan untuk penyandang disabilitas.

Penyandang disabilitas atau dikenal dengan difabel adalah seorang yang rentan dalam perlakuan diskriminasi, salah satu perlakuan diskriminasi yang dirasakan penyandang disabilitas adalah tidak adanya persamaan pada saat penerimaan kerja. Padahal UU Nomor 13 Tahun 2003 tentang Ketenagakerjaan, pada Pasal 5 menyebutkan bahwa setiap tenaga kerja memiliki kesempatan yang sama tanpa diskriminasi untuk memperoleh pekerjaan dan Pasal 6 menyebutkanbahwa setiap pekerja atau buruh berhak memperoleh perlakuan yang sama tanpa diskriminasi daripengusaha. Namun penyandang disabilitas masih sulit mendapatkan pekerjaan baik di instansi pemerintah maupun di perusahaan swasta, untuk tahun 2017 mencapai 100 orang mengikuti program partisipasi kerja dari disnaker sebanyak $2 \%$ dari jumlah tenaga kerja di perusahaan- perusahaan Kota Serang dan 1\% bekerja sebagai Aparatur Sipil Negara dengan rentan usia kerja 20 sampai 40 tahun. Beberapa masalah yang dihadapi antara lain rasa malu dan minder serta kurangnya kesadaran serta dukungan keluarga untuk memberikan pelatihan melalui program 
Pemerintah Kota Serang, dan banyak perusahaan yang tidak tahu atas UU No. 8 tahun 2016 tentang penyandang disabilitas yang mewajibkan penggunaan tenaga kerja disabilitas sebanyak $2 \%$ bagi instansi pemerintah dan $1 \%$ bagi perusahaan swasta dari jumlah seluruh karyawan di perusahaan tersebut (Pratama, 2018).

Model rekrutmen bagi penyandang disabilitas yang telah ditetapkan perusahaan ternyata masih memiliki berbagai kendala yang sangat berhubungan dengan faktor pendukung dan penghambat yang dialami penyandang disabilitas pada saat proses rekrutmen. Padahal model tersebut sudah dibuat sesuai dengan standar operasional prosedur yang jelas dan terperinci.Beberapa kendala pada model rekrutmen tersebut antara lain terbatasnya ketersediaan sumber dayaberkualitas, rendahnya tingkat pendidikan dan pengetahuan serta kriteria yang tidak dapat dipenuhicalon karyawan.

\section{TINJAUAN PUSTAKA}

\section{Konsep Rekrutmen}

Menurut Rivai (2004:158), Rekrutmen adalah suatu proses untuk mendapatkan sumber daya manusia yang memiliki kualitas guna menduduki jabatan atau pekerjaan tertentu pada perusahaan. Menurut Sjafri Mangkuprawira (2004:95), rekrutmen adalah proses penarikan sekelompok kandidat untuk mengisi posisi yang lowong dalam perusahaan. Berdasarkan teoriteori tersebut, dapat disimpulkan bahwa rekrutmen adalah serangkaian proses pencarian calon tenaga kerja yangmemiliki potensi dan minat sesuai dengan posisi yang dibutuhkan perusahaan.

\section{Model Rekrutmen}

Hasibuan (2010:44) menjelaskan bahwa terdapat dua metode rekrutmen, yakni:

1. Metode tertutup, rekrutmen dalam metode tertutup adalah cara menarik pelamar yang dilakukan dengan menginformasikan lowongan pekerjaan hanya kepada karyawan atau orang tertentu, sehingga menyebabkan jumlah lamaran yang masuk lebih sedikit, akibatnya lebih sulit untuk mandapatkan karyawan yang baik.

2. Metode terbuka, metode rekrutmen terbuka adalah cara penarikan karyawan dengan cara menginformasikannya secara luas tentang lowongan pekerjaan seperti media iklan atau lainnya. Tujuannya supaya jumlah lamaran yang masuk lebih banyak, sehingga perusahaan memiliki peluang besar memperoleh karyawan yang baik. 
Prosiding The 1st National Conference on Applied Business, Education, \& Technology (NCABET)"

Unversitas Bina Bangsa 2021

DOI Article : 10.46306/ncabet.v1i1.9

Standar Operasional Prosedur

Moekijat (2018) menjelaskan bahwa Standar Operasional Prosedur (SOP) ialah urutanlangkahlangkah (pelaksanaan pekerjaan), dimana, bagaimana, bilamana, di mana, dan siapa yangmelakukan pekerjaan tersebut. Menurut Sailendra (2015:11), Standar Operasional Prosedur (SOP)merupakan panduan terperinci yang digunakan untuk memastikan kegiatan operasional organisasiatau perusahaan berjalan dengan lancar. Berdasarkan teori-teori tersebut, dapat disimpulkan bahwaStandar Operasional Prosedur (SOP) merupakan langkah atau pedoman terperinci dalam mengerjakan suatu pekerjaan yang bertujuan untuk memperoleh hasil yang paling efektif.

\section{Fungsi Standar Operasional Prosedur}

Fungsi dari Standar Operasionel Prosedur antara lain sebagai berikut (Indah Puji, 2014:35) :

1. Tuntunan guna memperlancar tugas petugas/pegawai atau tim/unit kerja

2. Sebagai dasar hukum apabila terjadi penyimpangan.

3. Mengetahui dengan jelas segala hambatan dan mudah dalam melacaknya.

4. Mengarahkan petugas/karyawan untuk bersama-sama menjalankan disiplin dalam bekerja.

5. Sebagai pedoman dasar dalam melaksanakan pekerjaan yang bersifat rutin.

\section{Definisi Penyandang Disabilitas}

Menurut (Sugiono, dkk, 2014), Penyandang disabilitas merupakan seseorang yang mempunyai kelainan dan/atau yang dapat mengganggu aktivitas. Sedangkan WHO menjelaskan bahwa Penyandang disabilitas ialah suatu kehilangan atau ketidaknormalan baik psikologis, fisiologis maupun kelainan struktur atau fungsi anatomis. Berdasarkan pengertian mengenai penyandang disabilitas tersebut, dapat disimpulkan bahwa penyandang disabilitas merupakan suatu keterbatasan atau kehilangan kemampuan tertentu, yang dimiliki seseorang karena beberapa faktor. Kelainan Tubuh (Tuna Daksa) adalah individu yang memiliki gangguan gerak yang disebabkan oleh kelainan neuromuscular, terdapat beberapa jenis penyandang disabilitas fisik yaitu (Wisnuwardani, 2019): 1) Penyandang disabilitas yang bersifat bawaan; 2) Penyandang disabilitas sakit; 3) Penyandang disabilitas akibat kecelakaan (kehilangan organ tubuh); 4) Penyandang disabilitas polio dan lumpuh.

\section{Faktor yang Mempengaruhi Hak Rekrutmen Tenaga Kerja Penyandang Disabilitas Fisik}

Kehadiran Perda UU Nomor 13 Tahun 2019 di Kota Serang tentang Penyandang Disabilitas diharapkan bisa memberikan hak dan kesempatan yang lebih baik bagi penyandang disabilitas, mulai dari hak untuk hidup, mendapatkan pekerjaan, pendidikan, hingga kemudahan akses fasilitas 
umum. UU tersebut memang belum sepenuhnya mengakomodir harapan penyandang disabilitas, namun ada beberapa poin penting dari UU ini yang diharapkan bisa menggawangi implementasinya seperti :

1. Tentang pembentukan Komnas Disabilitas yang bertugas melaksanakan pemantauan, evaluasi, advokasi pelaksanaan penghormatan, perlindungan dan pemenuhan hak-hak penyandang disabilitas.

2. Terbentuknya lembaga yang menampung aspirasi dan tenaga kerja khusus orang-orang difabel, baik swasta maupun pemerintahan. Dengan adanya lembaga ini diharapkan mampu mewakili harapan difabel untuk dapat menikmati kehidupan kerja layaknya orang pada umumnya dan menambah kepercayaan diri, dengan mempekerjakan difabel pada bidang yang mereka kuasai,dan memperoleh hak yang setara ditargetkan untuk menyadarkan masyarakat bahwa difabel adalah warga Negara yang derajat dan kedudukannya sama serta mampu melakukan banyak hal.

3. Pihak dari lingkungan masyarakat, sudah saatnya untuk peduli terhadap sesama dan tidak memandang rendah pada suatu hal termasuk kepada kaum difabel.

\section{METODE PENELITIAN}

Metode yang digunakan dalam penelitian ini adalah penelitian kualitatif deskriptif. Untuk mengidentifikasi faktor pendukung dan faktor penghambat dalam proses rekrutmen tenaga kerja penyandang disabilitas menggunakan metode survey. Metode snowball digunakan untuk menetapakan Informan. Untuk data primer, diperoleh langsung dari Pejabat/Staf dinas ketenagakerjaan, ketua PPDI (Persatuan Penyandang Disabilitas Indonesia), dosen dari PTN (Untirta), mahasiswa dari PTN (Untirta), Founder DCC (Disabled Care Community) di Jakarta dan mahasiswa pascasarjana UMJ karyawan swasta di hotel ibis tanah abang. Wawancara dilakukan dengan terstruktur. Sedangkan data sekunder didapat dengan cara meminta langsung kepada Pejabat/Staf Dinas Ketenagakerjaan. Data berapa jumlah karyawan penyandang disabilitas tuna daksa yang bekerja di Kota Serang dan data lainnya terkait model rekrutmen bagi tenaga kerja penyandang disabilitas. 
Prosiding The 1st National Conference on Applied Business, Education, \& Technology (NCABET)"

Unversitas Bina Bangsa 2021

DOI Article : 10.46306/ncabet.v1il.9

HASIL DAN PEMBAHASAN

\section{Model Rekrutmen Calon Karyawan Penyandang Disabilitas}

Hasil penelitian dan wawancara yang telah dilakukan dapat dilihat dari Standart Operational Procedure rekrutmen bagi penyandang disabilitas adalah sebagai berikut :

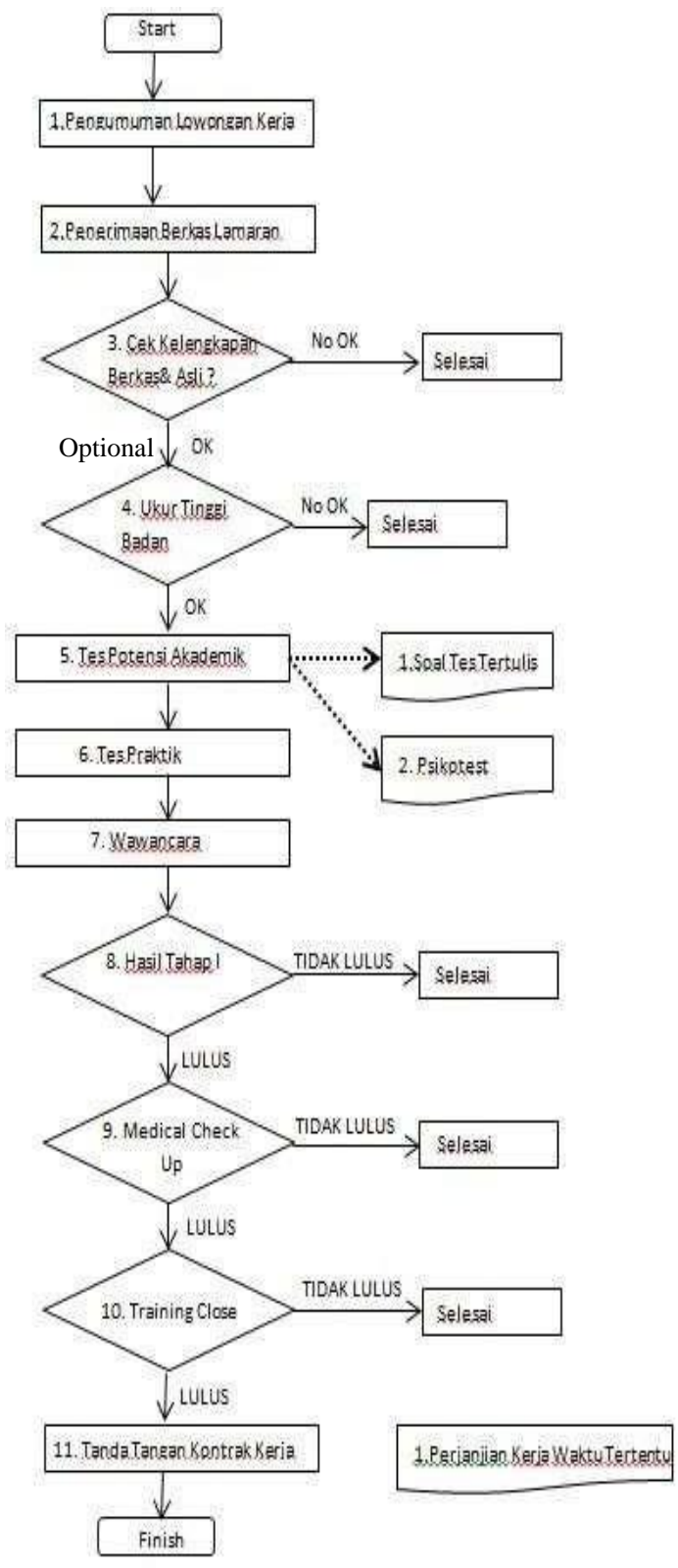

\section{Gambar 1. Model Rekrutmen Penyandang Disabilitas}

Sumber : Dinas Tenaga Kerja Kota Serang

Dengan adanya Standart Operational Procedure dapat dilihat alur proses rekrutmen calonkaryawan penyandang disabilitas yaitu :

a. Perusahaan membuat lowongan terkait lowongan pekerjaan 
b. Penerimaan dokumen lamaran dari calon karyawan

c. Pengecekan dokumen asli dan fotocopy berupa : 1) KTP (Kartu Tanda Penduduk); 2) BatasMinimal Usia Ketika Rekrutmen (18 Tahun); 3) Ijazah; 4) KK (Kartu Keluarga); 5) SKCK(Surat Keterangan Catatan Kepolisian); 6) Surat Keterangan Dokter; 7) Kartu Kuning; 8)Ukur Tinggi Badan.

d. Proses Tes Potensi Akademik (TPA), calon karyawan penyandang disabilitas mengisi soaltes yang telah disiapkan untuk mengetahui potensi yang ada dalam diri calon tenaga kerja.

e. Calon karyawan penyandang disabilitas harus mengikuti tes praktek yang telah disiapkanuntuk mengetahui seberapa cakap calon tenaga kerja dalam melakukan pekerjaan.

f. Proses wawancara calon karyawan penyandang disabilitas berdasarkan form Interview Sheet. Salah satu tujuannya adalah untuk mengetahui soft skill calon tenaga kerja

g. Pengolahan data hasil seleksi dan mengumumkan hasil tes calon karyawan penyandang disabilitas, bagi yang lulus dapat melanjutkan ke tahap berikutnya.

h. Calon karyawan penyandang disabilitas mengikuti Medical Check Up yang dilaksanakan di Rumah Sakit / Klinik yang ditunjuk oleh perusahaan, bagi yang lulus berhak melanjutkanke tahap selanjutnya.

i. Calon karyawan penyandang disabilitas mengikuti seleksi kesiapan kerja dengan mengikuti in class training perusahaan selama 7 hari dan On Job Training selama 3 hari.

j. Calon karyawan penyandang disabilitas yang telah dinyatakan lulus in class training akan dilanjutkan dengan tanda tangan surat perjanjian kontrak kerja.

\section{Kendala-Kendala dalam Perekrutan Karyawan Penyandang Disabilitas}

Berdasarkan hasil penelitian, terdapat beberapa kendala yang dialami pada proses rekrutmen antara lain sebagai berikut:

a. Kurangnya ketersediaan Sumber Daya Manusia yang berkualitas dari segi Pengetahuan Umum, Minat kerja dan Kesanggupan dalam melakukan tuntutan pekerjaan.

b. Rendahnya tingkat pendidikan calon karyawan penyandang disabilitas.

c. Rendahnya pengetahuan calon karyawan penyandang disabilitas.

d. Batasan kriteria yang tidak dapat dipenuhi oleh calon karyawan seperti kelengkapan berkaslamaran yang tidak memenuhi syarat yang diminta perusahaan.

\section{Faktor Pendukung}

Berdasarkan hasil observasi dan wawancara peneliti menyimpulkan bahwa faktor pendukung dalam proses rekrutmen tenaga kerja penyandang disabilitas tuna daksa di Kota Serang yaitu sebagai berikut : 
Prosiding The 1st National Conference on Applied Business, Education, \& Technology (NCABET)"

Unversitas Bina Bangsa 2021

DOI Article : 10.46306/ncabet.v1i1.9

1. Kemampuan (Skill):

Kemampuan atau skill yang dimiliki penyandang disabilitas tuna daksa merupakan salah satufaktor pendukung penyandang disabilitas tuna daksa untuk lolos pada tahap tes praktik dalammodel rekrutmen.

2. Relasi

Faktor relasi bagi penyandang disabilitas tuna daksa adalah bagian penting dalam proses mendapatkan kesempatan bekerja. Dengan adanya relasi seperti mengikuti organisasi, komunitaskomunitas penyandang disabilitas maka akan mempermudah penyandang disabilitas tuna daksa dalam memperoleh informasi terkait lowongan pekerjaan khusus untuk penyandang disabilitas tuna daksa.

\section{Pendidikan}

Pendidikan bagi penyandang disabilitas tuna daksa itu sangatlah penting karena semakin tingginya tingkat pendidikan akan mempermudah penyandang disabilitas tuna daksa untuk dapat lolos dalam tes potensi akademik dalam model rekrutmen.

\section{Faktor Penghambat}

Untuk faktor penghambat dalam proses rekrutmen tenaga kerja penyandang disabilitas tuna daksa di Kota Serang yaitu :

1. Dukungan keluarga

Dukungan keluarga adalah sebuah penguat dan support system bagi SDM penyandang disabilitas tuna daksa penyandang disabilitas tuna daksa, apabila tidak mendapatkan dukungandari keluarga, maka penyandang disabilitas itu akan berdiam diri di tempat, tidak berani dan tidak akan bisa maju dan berkembang.

2. Kurangnya semangat dari diri sendiri

Semangat dari diri sendiri merupakan faktor penting dalam memperoleh pekerjaan, hal ini tergantung dari bagaimana SDM penyandang disabilitas tuna daksa itu sendiri. Kurangnya semangat dan keinginan yang kuat untuk berkembang dan maju, dari diri seorang penyandang disabilitas tuna daksa maka hal ini tentu akan menghambat penyandang disabilitas tuna daksa dalam proses mencari pekerjaan.

3. Aksesbilitas

Pelayanan aksesbilitas adalah untuk mendapatkan kemudahan yang disediakan bagipenyandang disabilitas tuna daksa dalam penggunaan fasilitas sarana dan prasarana umum sudah menjadi tuntutan yang wajib dipenuhi oleh pemerintah dan masyarakat. 


\section{Lingkungan}

Faktor lingkungan bisa menjadi faktor penghambat karena belum terciptanya lingkungan yang inklusi di Kota Serang. Sehingga membuat penyandang disabilitas tuna daksa, cenderung merasa minder, drop dan takut, khususnya dalam mencari pekerjaan

\section{KESIMPULAN}

Kegiatan rekrutmen bagi setiap perusahaan merupakan hal yang sangat penting guna mendapatkanSumber Daya Manusia yang berkualitas dengan melalui tahapan seleksi. Berbagai kendala dalam model rekrutmen seperti ketersediaan sumber daya berkualitas yang terbatas, rendahnya tingkat pendidikan dan pengetahuan serta batasan kriteria yang tidak dapat dipenuhi oleh calon karyawandisebabkan oleh hasil identifikasi dalam proses rekrutmen tenaga kerja penyandang disabilitas fisik, diantaranya faktor pendukung dan faktor penghambat dalam proses rekrutmen tenaga kerja penyandang disabilitas fisik di Kota Serang. Faktor pendukung antara lain kemampuan (Skill), relasi, pendidikan. Sedangkan faktor penghambat terdiri dari kurangnya dukungan keluarga, kurangnya semangat dari diri sendiri, aksesbilitas dan lingkungan.

\section{UCAPAN TERIMAKASIH}

1. Kepada kedua orang tua yang senantiasa memberikan do'a dan dukungannya sehingga penulis dapat menyelesaikan penelitian ini.

2. Dr. H.Furtasan Ali Yusuf, S.E., S.Kom., M.M, selaku Rektor Universitas Bina Bangsa yang telah berperan aktif dalam meningkatkan mutu dan kualitas Universitas Bina Bangsa menjadiperguruan tinggi yang lebih baik.

3. Kepada seluruh Dosen, staf administrasi, rekan-rekan mahasiswa dan sahabat yang telah memberikan bantuan sehingga penulis dapat menyelesaikan penelitian ini.

\section{DAFTAR PUSTAKA}

Annie Sailendra, 2015, Langkah-langkah Praktis Membuat SOP, Yogyakarta: Trans Idea Publishig Indah Putri Hartantik, 2014, Buku Praktis Mengembangkan SDM, Yogyakarta: Laksana Malayu SP. Hasibuan, 2010, Manajemen Sumber Daya Manusia, Jakarta: Bumi Aksara Moekijat, 2018, Administrasi Perkantoran, Bandung: Maju Mundur Pratama, Aldi Budi. 2018. Pemenuhan Hak Atas Pekerjaan Bagi Penyandang Disabilitas di Kota Serang, Universitas Islam Indonesia:Yogyakarta. 
Prosiding The 1st National Conference on Applied Business, Education, \& Technology (NCABET)"

Unversitas Bina Bangsa 2021

DOI Article : 10.46306/ncabet.v1il.9

Putra, Arta Rusidarma, Ombi Romli. 2018. Analisis Peran Pemerintah Daerah Terhadap Potensi Wilayah Untuk Pengembangan Usaha Kerajinan Gerabah (Studi Di Kerajinan Gerabah Desa Bumi Jaya Kecamatan Ciruas Kabupaten Serang), Ikraith Ekonomika, Vol.1, No.2,Hal.33.

Sjafri Mangkuprawira, 2004, Manajemen Sumber Daya Manusia Strategik, Jakarta: Ghalia Indonesia Veithzal Rivai, 2004, Manajemen Sumber Daya Manusia, Jakarta: PT . Raja Grafindo Persada

Sugiono, Ilhamuddin, Arief Rahmawan. 2014. Klasterisasi Mahasiswa Difabel Indonesia Berdasarkan Background Histories dan Studying Performance, Indonesia Journal of Disability Studies, Vol.1, No.1, Hal.20-21.

Wisnuwardani, Dyah Puspita. 2019. "Ada 4, Kenali Ragam Disabilitas", https://m.liputan6.com/disabilitas/read/4126110/ada-4-kenali-ragam-disabilitas, diaksespada 04 Desember pukul 12:17 WIB. 